\title{
Most recent investigation of peopling of Bosnia and Herzegovina: DNA approach
}

\author{
Damir Marjanović ${ }^{1,2}$, Naris Pojskić ${ }^{1}$, Belma Kalamujić ${ }^{1}$, Narcisa Bakal', Sanin Haverić ${ }^{1}$, \\ Anja Haverić ${ }^{\text {, Adaleta Durmić }}{ }^{\text {, Lejla Kovačević }}{ }^{1}$, Katja Drobnič ${ }^{3}$, \\ Rifat Hadžiselimović 1 , Dragan Primorac 4,5 \\ 1 Institute for Genetic Engineering and Biotechnology, University of Sarajevo, Bosnia and Herzegovina \\ damir.marjanovic@ingeb.ba \\ 2 Center for Integrative Genomics, Molecular Diagnostics, Cell and Gene Therapy, "Rudjer Bošković" \\ Institute, Zagreb, Croatia \\ 3 Forensic Laboratory and Research Center, Ministry of the Interior, Ljubljana, Slovenia \\ 4 Medical School at Split University, Split, Croatia \\ 5 Medical School at Osijek University, Osijek, Croatia
}

\begin{abstract}
Many historical episodes marked Bosnia and Herzegovina as a significant ethnic crossroads, which makes it a very interesting site for various population studies. The first stages of these complex investigations were based on observations of numerous phenotype markers. The following phase, which was relatively brief, was dominated by the use of different cytogenetic markers. Finally, at the beginning of this century, the molecular-genetic diversity of the BiH population became the focus of modern research. Autosomal and Y-STR markers, together with mitochondrial haplogroup (Hg) diversity were initially used in the examination of isolated groups, as well as the whole population of modern Bosnia and Herzegovina. The most recent study describes the distribution of Y-chromosome haplogroups in the three main ethnic groups in Bosnia and Herzegovina, and suggests a preliminary hypothesis for the process of peopling this area.
\end{abstract}

IZVLEČEK - Veliko zgodovinskih dogodkov je zaznamovalo Bosno in Hercegovino kot pomembno etnično stičišče, ki je zelo zanimivo za različne populacijske študije. Začetki kompleksnih raziskav so povezani z opazovanjem številnih fenotipskih označevalcev. V naslednji fazi je prevladala uporaba različnih citogenetskih označevalcev. Na začetku tega stoletja so raziskave usmerjene v molekularno-genetsko raznolikost BiH populacije. Pri raziskavah izoliranih populacij, kot tudi celotne človeške populacije moderne Bosne in Hercegovine, so na začetku uporabili avtosomalne in Y-STR označevalce skupaj z raznolikostjo mitohondrijske haploskupine (Hg). Najnovejša študija opisuje porazdelitev haploskupin Y-kromosoma pri treh glavnih etničnih skupinah v Bosni in Hercegovini in izdela preliminarni scenarij procesa poselitve tega področja.

KEY WORDS - molecular markers; Y-chromosome; Last Glacial Maximum; Paleolithic; Neolithic

\section{Bosnia and Herzegovina: from the most ancient times to the present}

Because of its great number of small, more or less isolated, indigenous populations, Bosnia-Herzegovina represents a very interesting area for population-genetic surveys of different levels and approaches. The fascinating diversity of local human populations (obvious even in phenotype characteristics of individu- als), as well as various levels of reproductive isolation can be attributed to the simultaneous and interactive effects of a vast number of factors (geographical, ethnic, religious etc.). Within those areas, each local population exhibits a different degree of openness and isolation and has unique relationships with 
ancestral populations. The results of previous studies show that classic "islands in the land" exist in some regions (Marjanović et al. 2004).

Migration played a very important role in shaping recent conditions, such as, in particular, those relating to the peopling of central Balkan, as well as small regional movements, which were rather frequent because of the geographical position of this area (Malcolm 1994).

Archaeological finds indicate that the territory of modern Bosnia-Herzegovina was continuously settled since the Palaeolithic (Imamovic et al. 1998). Stone tools found in north Bosnia date to more than 50000 years ago (Imamovic et al. 1998). However, the most interesting prehistoric traces of civilization date from the Neolithic.

At the beginning of the second millennium $\mathrm{BC}$, the discovery of considerable sources of various kinds of metals attracted new settlers to the Balkan region, including Bosnia-Herzegovina as its central part. In this period the area was inhabited by Illyrian tribes. At the same time, Gals' invasions caused the Illyrians to migrate and settle in the eastern parts of modern Bosnia (Wilkes 1992).

By the end of the first century BC, after a hundredyear war, the Romans had defeated all the Illyrian tribes. The Illyrian province was under Roman rule for over 500 years. This was of great importance for this region that, after the construction of military roads and opening of numerous mines (silver, gold, copper, iron etc.), became once again the destination for many adventurers from all parts of the Roman Empire (Klaic 1990). The final division of the Roman Empire made the Balkans an unstable borderland and the crossroads of civilizations, peoples and religions.

Two crucial, relatively recent events, along with a number of more minor historic episodes, laid the foundations for the current population structure of region.

The first event was the great migration in the sixth and seventh centuries AD that caused the final fall of, first, Western then the Eastern Roman Empire. Documentary evidences suggest that the Goths were the first immigrants to this region (Malcolm 1994); shortly thereafter the Avars and Slavs arrived. In spite of the numerous invaders, there are reasons to believe that the first invasions were blunted by the resistance of well-armed resident Illyrians and the specific landscape, and that the local inhabitants probably completely assimilated most of the first immigrants (Imamovic et al. 1998). According to some authors, this situation persisted for the next couple of decades, when the total 'slavization' of this area began with the arrival of two new Slavic tribes and the foundation of their powerful neighboring countries (Imamović et al. 1998). The present territory of Bosnia-Herzegovina is located between the areas inhabited by Croats (to the west) and Serbs (to the east). The first document mentioning this region was written by Constantine Porphyrogenitus in 958 (1967). It mentions that Bosnia, being a political and geographical subject, is located in a narrow area along the river. This part of history, in the absence of detailed written documents, is something of a 'twilight zone' for the interpretation of the political situation of that time. Principally, different understandings and presentations of historical facts have been dictated by ideology and politics. However, great mysteries such as the Bosnian heretical church, the term 'Bogomils' (Rački 1931) and the origin of isolated Bosnian populations remain issues for the future. A key fact is that the territory of Bosnia-Herzegovina at that time was the border, or the crossroads of two religious philosophies, Orthodox and Catholic.

The second important historical moment for this region was the expansion of the Ottoman Empire in the fifteen century. The conversion to Islam of a large part of the population was a fundamental process in the creation of modern Bosnian history. It was a long-term process, which took 150 years before Muslims were the majority in the former Bosnian sandzak (Malcolm 1994). This process is somewhat controversial, and the only thing that can be refuted with certainty is the hypothesis of forced mass conversion of the indigenous population. Unfortunately, historical dilemmas about some stages of establishing modern Bosnia-Herzegovina society have provided opportunities for various ideological, political, national, even nationalistic manipulations and distortions of the facts.

Modern Bosnia-Herzegovina is a multi-ethnic and multi-religious country, with a very stormy recent history. In various public and scientific media, many recent conflicts were sought through different interpretations of some parts of its history. Therefore, every population-genetic study based on the analysis of molecular markers suitable for detecting migration and micro-evolutionary phenomena, with 
utterly reliable and exclusively scientific result presentation, can create new perspectives, but also raise questions about the structuring demographic characteristics of this area.

\section{The development of population genetic studies}

Fundamental genetic studies of different human, animal or plant populations are based on a preliminary understanding of the nature of molecular marker variations in observed populations. This universal rule, applicable to a wide range of organisms as potential research subjects, is especially important when $\mathrm{Ho}^{-}$ mo sapiens is the focus of study.

Modern population-genetic studies have changed significantly, especially in the last two decades. Previous studies were based on the observation of classical phenotypic markers. Population-genetic studies that simultaneously analyze the diversity of numerous, carefully selected, phenotypic characteristics can result in interesting information about micro-changes in the genetic structure of observed populations over a certain period. However, many of the informative phenotypic markers are limited by a lack of clarity in defining the heritable and non-heritable components that form most of the phenotypic attributes of an organism, especially those which are easiest to detect.

Human population genetics often uses intra- and inter-population distributions of genetic molecular markers in and between analyzed parts of population in order to elucidate their demographic and migration history (Wells et al. 2001). The development of new molecular-biological techniques has improved the molecular markers system. Among these markers, of primary importance are the STR (short tandem repeats) sequences, located on autosomal chromosomes (Bowcock et al. 1994), and SNP (single nucleotide polymorphisms) haplotypes (Jin et al. 1999). Even nowadays, these two kinds of markers can significantly contribute to a better understanding of the demographic and migration processes that affected the gene pool of now living populations.

Polymorphic markers, such as biallelic and STR, located in the non-recombining part of Y-chromosomes (NRY), are also known as holiandric markers, because of their transmission from father to son. The absence of recombination, as well as patrilocal marriage in approximately $70 \%$ of modern societies, makes this unique item of human chromosomal sets exceedingly useful in the study of large-scale evo- lutionary events in human history and population genetics phenomena in large and small, relatively isolated communities.

In the past few years a substantial amount of population data regarding the non-recombining part of Y-chromosomes has appeared (YCC 2002 and references therein). The spate of surveys in this field began with papers in the mid-1980's (Casanova et al. 1985) Markers located in this part of the human genome have an important role in evolutionary studies (Hammer et al. 1996; Poloni et al. 1997; Rosser et al. 2000), as well as in forensic (Jobling et al. 1997) and medical genetics (Jobling and Tyler-Smith 2000). The most frequently used markers at that time were RFLP (restriction fragment length polymorphism) or STR loci (YCC 2002). A historic breakthrough was made by the utilization of the DHPLC (denaturing high-performance liquid chromatography) method in the investigation of binary markers from the non-recombining portion of Y-chromosomes (NRY) (Underhill et al. 1997). As reported in some papers (Underhill et al. 2000; Shen et al. 2000; Hammer et al. 2001), over a short period of time, this method allowed the identification of over 200 SNPs and short insertion/deletion (indel) positions (YCC 2002). A very low mutation rate characterizes these polymorphisms' (named for this reason Unique Event Polymorphisms - UEP), making them suitable for the identification and detection of parental lineages stretching back thousands of years (YCC 2002). In order to set up a more flexible nomenclature system and to provide a complex NRY binary haplogroup tree, Y Chromosome Consortium (YCC), established by leading experts in Y-chromosome analysis, suggested a universal system in 2002 that is widely accepted today (YCC 2002). According to this system, Y-specific binary haplogroups (often denoted simply as haplogroups) refer to chromosome clusters characterized by the deepest UEPs. These clusters are more stable, but at the micro-evolutionary level, less informative than haplotypes defined by the more variable STR markers (Jobling and Tyler-Smith 2003). On the whole, a total of 16 major haplogroups (denoted by letters: A-R) were identified and the study of their distribution (phylogeography) provided important information about the peopling of different geographical areas, post-glacial and Neolithic expansions (Underhill et al. 2001). As to Europe, more than $90 \%$ of the Y-chromosomes belong to a few (E-SRY4064, I-M170, G-M201, J-12f2, R-M17and R-269) principal haplogroups (Semino et al. 2000; 2004; Cruciani et al. 2004; Rootsi et al. 2004). 
Overview of population-genetic studies in Bosnia and Herzegovina during the last three centuries

Anthropo-genetic studies in Bosnia-Herzegovina were begun by the Austro-Hungarian government (Hadziselimovic 1984). The first known bio-anthropological analyses of the population conducted by Austro-Hungarian army doctors can be considered an initial phase in determining its genetic structure (Himmel 1887).

It is important to stress that all of the studies were based primarily on the observation of phenotypic traits such as blood groups (Kalić, Kostić 1934; Berberović et al. 1973), color blindness (Berberović 1969), the shape of lobules (Hadziselimovic 1970), PTC sensibility (Berberović et al. 1973), thumb flexibility (Hadziselimović \& Brdar 1979), or analysis of the effect of some factors that disturb genetic equilibrium (Hadziselimović 1983).

The first steps were taken in investigating the variety of the fundamental, molecular-nuclear and mitochondrial DNA markers for diversity analyses of isolated Bosnia-Herzegovina populations at the beginning of this century (Marjanović et al. 2004; Kapur et al. 2004; Marjanovic et al. 2005). Following analysis of STR marker variation, autosomal (Marjanović et al. 2006), and Y-chromosome markers (Marjanović et al. 2005a) were studied in order to establish a reference sample and to incorporate data about the molecular biodiversity found in $\mathrm{BiH}$ in a regional database (REBID-a).

Finally, the most interesting and controversial results were obtained trough the observation of $28 \mathrm{Y}$ chromosome biallelic markers within 256 males (90 Croats, 81 Serbs and 85 Bosniacs) from Bosnia-Herzegovina (Marjanović et al. 2005b; 2005c).

\section{The Y-chromosome approach (summary of pub- lished articles)}

The people of Bosnia-Herzegovina display European specific haplogroups that probably appeared in different glacial refuge areas of Europe (I-M170, RM17 and RM269 from Balkan, Ukrainian and Franco-Cantabrian refuges, respectively), and haplogroups considered to have originated in Africa (E-SRY4064) and the Middle East (J-12f2) and to have arrived in Europe through a prolonged gene flow.

However, the presence of the $\mathrm{HgI}$ sub-haplogroup I-P37 in more than $50 \%$ of the examined Y chromo- somes sets the population of Bosnia-Herzegovina apart from the majority of other European regions. Taking into account that a Palaeolithic origin for the P37 mutation in this Balkan district has been suggested (Rootsi et al. 2004), it is possible that the postglacial expansion of a population with a high frequency of I-P37 from one of the refuges in the Balkans played a major role in the creation of the gene pool of modern Bosnia-Herzegovina.

$\mathrm{HgE}$ is the second most frequent haplogroup in Bosnia-Herzegovina; its presence in Europe has been attributed to multiple migrations from the Middle East and North Africa during and after the Neolithic (Cruciani et al. 2004; Semino et al. 2004). HgE is almost exclusively represented by the sub-clade EM78. It is worth mentioning that the clinal distribution in Europe of E-M78 and its internal micro-satellite variance have been attributed to dispersals in Neolithic and post-Neolithic times from the Balkans to all directions, as far as Iberia to the west and, probably also to Turkey in the southeast (Cinnioğlu et al. 2004; Cruciani et al. 2004; Semino et al. 2004). In this framework, our data suggest that this expansion would have significantly affected the gene pool of Bosnia-Herzegovina.

Haplogroup $\mathrm{J}$ is another haplogroup that arrived in Europe from the Middle East, and its sub-clades probably marked complex migration processes during and after the Neolithic period (Cinnioglu et al. 2004; Di Giacomo et al. 2004; Semino et al. 2004). In the Bosnia-Herzegovina population this haplogroup, with almost all of its known sub-clades, is found mainly in the Bosniacs. The detected J sub-clades are J-M267, which has been associated with Arab expansion; JM92, which suggests genetic links between Anatolia and southern Italy; J-M67, which is frequent in the Caucasus; and finally J-M102, which shows frequency peaks in the southern Balkans and central-southern Italy.

$\mathrm{R}-\mathrm{M} 17$ is the prevalent sub-haplogroup of $\mathrm{Hg} \mathrm{R}$, as previously observed in other eastern European populations (Semino et al. 2000; Passarino et al. 2001; Wells et al. 2001). Its frequency perfectly fits the expected distribution of R-M17, which is found almost exclusively in Eastern Europe, with a decreasing gradient from northeast to south-west. This gradient, initially attributed to expansion(s) from a Ukrainian glacial refuge (Semino et al. 2000), could also be due to infiltrations of Indo-European speaking peoples from southern Russia about 2000 years ago (Jovanović 1979; Barać et al. 2003), as well 
as to the arrival of Slav clans during the 6th and $7^{\text {th }}$ centuries. However, to evaluate this latter hypothesis, detailed analyses of R-M17 and internal STR diversity in the Bosnia-Herzegovina population are required.

The presence of the R-M269 sub-haplogroup in the sample is of interest. Despite the relatively low frequency of this marker, it indicates that the gene pool of the ancestral population(s) of the Franco-Cantabrian refuge area also contributed to some extent to this region of the Balkans, as additionally attested by analyses of the mtDNA (Achilli et al. 2004).

The first PC analysis (Marjanovic et al. 2005c) suggests that the three ethnic groups are genetically extremely close to each other, and closely related to other populations of the Balkans. However, the second PC tends to separate the Croat group from other populations, probably as a result of the aforementioned effects of genetic drift and founding events on this ethnic group.

On the whole, our data suggest three main factors in the gene pool foundation of modern Bosnia-Herzegovina: (a) post-LGM expansion - possibly from a LGM refuge area in the Balkans, (b) complex migratory processes from Central Asia and Eastern Europe and (c) the numerous Neolithic and Post-Neolithic migration events that contributed haplogroups considered to be of African and Middle Eastern origin.

\section{The main objectives of possible future studies of the peopling of Bosnia and Herzegovina}

The outcome of this study is a possible account of the pattern of settlement in the area of modern Bosnia-Herzegovina. For the purpose of further elaboration it is necessary to insist on more of the basic parameters in future studies.

A multi-disciplinary approach is required in order to investigate fully all the pre-historic and historical events relative to the peopling of Bosnia-Herzegovina and the Balkans. All historical, archaeological and other findings relevant to determining migratory factors and modern micro-migratory processes should be analyzed. The results of this study should be compared to those of previous population-genetic studies based on observations of a wide range of both classic and molecular markers. Presented scenario, based on the results of holandric marker variation analysis, could benefit from such an approach.
The second parameter, which points to the dating of primary mutations in samples of the Bosnia-Herzegovina population, is highly notable. With the intention of estimating the possible time of mutation occurrence, analyses of Y-chromosome STR markers, and their frequencies and correlations within the detected haplogroups can be of great value. The results of these analyses would facilitate the precise reconstruction of regional migration patterns. Preliminary results based on the observation of 100 males from Bosnia and Herzegovina, have already yielded interesting results (Marjanović et al. 2006). Eighty-one different Y-STR haplotypes (from a total number of 100 samples obtained) were detected: 69 of them were unique, 7 appeared twice, 4 appeared three times, and 1 five times. Six of twelve not singleton haplotypes were shared by different population groups: two of them by Croats and Bosniacs, two by Bosniacs and Serbs, and the last two by Serbs and Croats, thus testifying almost certainly to recent gene flows between groups.

Most importantly, the results must be evaluated with an expanded sample. The sample of 256 individuals is larger (in European proportions and for such a relatively small population as Bosnia-Herzegovina) than many other samples investigated so far. Also, sample size for each of the three major ethnic groups completely meets the standards for this type of investigation, and is larger than those used in previous European studies of much larger populations than this one. The fact that the subjects are from more than 50 different locations in Bosnia-Herzegovina speaks in favor of a representative sample. However, regarding the high specificity and close relations of the ethnic groups, their common historical development, specific micro-migrational paths and the specific historical circumstances under which these groups developed, it is important to examine the intra-population diversity of regional subpopulations. For instance, the Croat population could be analyzed including sub-samples from Herzegovina, Middle Bosnia and Posavina; the Serbs through Herzegovina, Eastern Bosnia and Krajina groups; while the Bosniacs could be typed by comparing Herzegovina, East-Middle Bosnia and Western Bosnia groups. However, all the other demographic-genetic characteristics of the local groups of these populations can be taken into consideration. This approach can resolve the question of whether differences observed through this study are due to inter-populational (ethnical) or, more probably, intra-populational (regional) characteristics. 
Until these complex studies are conducted, it is important to state that all findings, implications, hypotheses, reconstructions and models of this study are based on the results of the analyses of a screeningsample of the Bosnia-Herzegovina population and its relation to previously studied Eurasian populations.

Recent scientific studies from this field (Semino et al. 2000; Barać et al. 2003, and others) offer one truly interesting and completely new scenario. However, extreme caution is required in presenting these scientific results in the public media in order to avoid misinterpretation of the facts and unscientific speculation that could have unforeseeable consequences.

\section{ACKNOWLEDGEMENTS}

All Y-chromosome SNP analyses and results were obtained at the Dipartimento di Genetica e Microbiologia 'A. Buzzati-Traverso', Universit'a di Pavia (Pavia, Italy). Therefore, we are grateful to Professor Silvana Santachiara-Benerecetti, Antonio Torroni and especially to Ornella Semino and her associates (Simona, Silvia, Alessandro, Enza etc.) for their kindness and support.

\section{REFERENCES}

BARAĆ L., PERIČIĆ M., KLARIĆ M. et al. 2003. Y chromosomal heritage of Croatian population and its island isolates. European Journal of Human Genetics 11: 535542.

BERBEROVIĆ Lj. 1969. Incidence of colour blindness in a sample of the population of Sarajevo (Bosnia). Bulletin des Sciences, Sect A 14: 11-12.

BERBEROVIĆ Lj., HADZISELIMOVIĆ R., KARANAĆ V. 1973. Sistem sklapanja brakova u SR BiH, s obzirom na AB0 u $\mathrm{Rh}$ sistem krvnih grupa (analiza grupa slučajeva spornog očinstva). II jugoslavenski simpozijum izhumane genetike, Rezimei referata: 41.

BERBEROVIĆ Lj., HADZISELIMOVIĆ R., HADZIĆ A. 1973. The Ability of Tasting PTC in a Group of School Children from Banja Luka. Bulletin des Sciences, Sect. A 18: 4-6.

BOWCOCK A. M, RUIZ-LINARES A., TOMFOHRDE J., MINCH E., KIDD J. R., OEFNER P. J. 1994. High resolution of human evolutionary trees with polymorphic microsatellites despite a constraint in allele length. Nature 368: 455457.

CASANOVA M., LEROY P., BROUCEKKINE C. et al. 1985. A human Y-linked DNA polymorphism and its potential for estimating genetic and evolutionary distance. Science 230: 1403-1406.

CRUCIANI F., FRATTA L. A., SANTOLAMAZZA R. et al. 2004. Phylogeographic analysis of haplogroup E3b (E-M215) Y chromosomes reveals multiple migratory events within and out of Africa. American Journal of Human Genetics 74: 1014-1022.
HADZISELIMOVIĆ R. 1970. Podaci o učestalosti tipova ušne jagodice (lobulus auriculae) kod stanovništva Sarajeva. Genetika 2: 155.

1983. Diferencijalna reprodukcija kao mogući faktor genetičkog drifta u stanovništvu Bosne i Hercegovine. Simpozijum "Savremena populaciono - genetička istraživanja u Jugoslaviji (Sarajevo), Knjiga saopštenja: 121.

1984. Razvojne faze i pristupni modeli savremenih populaciono - genetičkih istraživanja kvalitativne varijacije u stanovništvu Bosne i Hercegovine. Genetika 3: 223-231.

HADZISELIMOVIĆ R., BRDAR D. 1979. Populacijsko genetička analiza distalne ekstenzibilnosti palca u stanovništvu Prijedora. Godišnjak Biološkog Instituta 32: 117.

HAMMER M. F., ZEGURA S. L. 1996. The role oh the Y chromosome in human evolutionary studies. Evolutionary Anthropology 5: 116-134.

HAMMER M. F., KARAFET T. M., RED A. J. et al. 2001. Hierarchical patterns of global human $\mathrm{Y}$ chromosome diversity. Molecular Biology and Evolution 18: 1189-1203.

HIMMEL H. 1887. Die Soldatenmaterial der Herzegowina in Anthropologisher Beziehung. Mittelungen der Anthropologischen Gesellschaft in Wien 17: 84.

IMAMOVIĆ E., LOVRANOVIĆ D., NILEVIĆ B. et al. 1998. Bosna i Hercegovina - od najstarijih dana do Drugog svjetskog rata. Sarajevo: Bosanski kulturni centar. 
JIN L., UNDERHILL P. A., DOCTOR V. et al. 1999. Distribution of haplotypes from a chromosome 21 regions distinguishes multiple prehistoric human migrations. Proceedings of the National Academy of Sciences of the United States of America 96: 3796-3800.

JOBLING M. A., PANDYA A., TYLER-SMITH C. 1997. The Y chromosome in forensic analysis and paternity testing. International Journal of Legal Medicine 110: 118-124.

JOBLING M. A., TYLER-SMITH C. 2000. New uses for new haplotypes the human Y chromosome, disease and selection. Trends in Genetics 16: 356-362.

2003. The human Y chromosome: an evolution marker comes of age. Nature Reviews Genetics 4: 598-612.

KAPUR L., POJSKIĆ N., MARJANOVIĆ D., DURMIĆ A., BAJROVIĆ K., HADŽISELIMOVIĆ R. 2003. MtDNA diversity in local human populations after war resettlement. $2^{\text {nd }} D N A$ polymorphisms in human populations, Paris, Abstracts.

KALIĆ D., KOSTIĆ D. 1934. Krvne grupe u našem narodu. Glasnik CHZ 17: 1-3.

KLAIĆ V. 1990. Povijest Bosne do propasti kraljevstva (reprint). Sarajevo: Svjetlost.

MALCOLM N. 1994. Bosnia: A Short History. Macmillan London Limited Copyright. London.

MARJANOVIĆ D., KAPUR L., DROBNIČ K., BUDOWLE B., HADZISELIMOVIĆ R. 2004. Comparative Study of Genetic variation at fifteen STR loci in three isolated populations of Bosnian mountain area. Human Biology 76: 15-31.

MARJANOVIĆ D., KAPUR L., POJSKIĆ N., HADŽISELIMOVIĆ R. 2005. Diversity in the studies of genetic distance among isolated human population in Bosnia. Humane Evolution 20: $157-166$.

MARJANOVIĆ D., BAKAL N., POJSKIĆ N. et al. 2005a. Population data for the twelve Y-chromosome short tandem repeat loci from the sample of multinational population in Bosnia and Herzegovina. Journal of Forensic Science 50: $223-225$.

MARJANOVIĆ D., FOMARINO S., BAKAL N. et al. 2005b. Ychromosome bi-allelic and STR markers in the three main ethnic groups of modern Bosnia and Herzegovina. European Journal of Human Genetics 13 (Suppl. 1): 339.

MARJANOVIĆ D., FOMARINO S., MONTAGNA S. et al. 2005c. The peopling of modern Bosnia-Herzegovina: Ychromosome haplogroups in the three main ethnic groups. Annals of Human Genetics 69: 757-764.
MARJANOVIĆ D., BAKAL N., POJSKIĆ N. et al. 2006. Allele Frequencies for 15 Short Tandem Repeat Loci in a Representative Sample of Bosnians and Herzegovinians. Forensic Science International 156: 79-81.

PASSARINO G., CAVALLERI G. L., LIN A. A. et al. 2002. Different genetic components in the Norwegian population revealed by the analysis of mtDNA and $\mathrm{Y}$ chromosome polymorphisms. European Journal of Human Genetics 10: 521-529.

POLONI E. S., SEMINO 0., PASSARINO G. et al. 1997. Human genetic affinities for Y-chromosome P49a,f/TaqI haplotypes show strong correspondence with linguistics. American Journal of Human Genetics 61: 1015-1035.

PORPHYROGENITUS C. 1967. De Administrando Imperio - reproduction. Dumbarton Oaks Center for Byzantine Studies. Washington D.C.

RAĆKI F. 1931. Bogumili i Patareni. Srpska kraljeva akademija. Beograd.

ROSSER Z. H., ZERJAL T., HURLES M. E. et al. 2000. Y chromosomal diversity in Europe is clinical and influenced primarily by geography rather then by language. American Journal of Human Genetics 67: 1526-1543.

ROOTSI S., MAGRI C., KVISLID T. et al. 2004. Phylogeography of Y-chromosome haplogroup I reveals distinct domains of prehistoric gene flow in Europa. American Journal of Human Genetics 75: 128-137.

SEMINO O., PASSARINO G., OEFNER P. J. et al. 2000. The genetic legacy of paleolithic homo sapiens in extant Europeans: a Y chromosome perspective. Science 290: 11551159.

SEMINO 0., MAGRI C., BENUZZI G. et al. 2004. Origin, diffusion, and differentiation of Y-chromosome haplogroups $\mathrm{E}$ and J: Inferences on the neolithization of Europe and late migratory events in the Mediterranean area. American Journal of Human Genetics 74: 1023-1034.

SHEN P., WANG F., UNDERHILL P. A., FRANCO C. et al. 2000. Population genetic implications from sequence variation in four Y chromosome genes. Proceedings of the National Academy of Sciences of the United States of America 97: 7354-7359.

TASIĆ N., DIMITRIJEVIĆ S., JOVANOVIĆ B. 1979. Prehistory of South Slavic Countries. Svjetlost. Sarajevo.

UNDERHILL P. A., JIN L., LIN A. A. et al. 1997. Detection of numerous biallelic polymorphisms by denaturing highperformance liquid chromatography. Genome Research 7: 996-1005. 
UNDERHILL P. A. , SHEN P., LIN A. A. et al. 2000. Y chromosome sequence variation and the history of human population. Nature Genetics 26: 358-361.

UNDERHILL P. A,. PASSARINO G., LIN A. A. et al. 2001. The phylogeography of Y chromosome binary haplotypes and the origins of modern human populations. Annals of $\mathrm{Hu}$ man Genetics 65: 43-62.

WELLS R. S., YULDASHEVA N., RUZIBAKIEV R. et al. 2001. The Eurasian heartland: a continental perspective on Y- chromosome diversity. Proceedings of the National Academy of Sciences of the United States of America 98: 10244-10249.

WILKES J. 1992. The Illyrians. Blackwell Publisher. Oxford.

Y CHROMOSOME CONSORTIUM (YCC). 2002. A nomenclature system for the tree of human Y-chromosomal binary haplogroups. Genome Research 12: 339-348. 